\title{
The Development of Creambath Preparation with Combination of Garlic Extract (Allium sativum L.) and Custard Apple Seeds Extract (Annona squamosa L.) as Anti-Dandruff and Anti Head Lice (Pediculus humanus capitis)
}

\author{
Mudita*, Swasono R Tamat, Agung Eru Wibowo \\ Faculty of Pharmacy, Universitas Pancasila, Jakarta
}

\begin{abstract}
Allicin and ajoene are active compounds in garlic which have proven to be of benefit as antifungal. Meanwhile, the content of oleic acid and triglycerides from the custard apple seeds extract showed antifungal activity in vitro. This study aimed to obtain a preparation of creambath combination of garlic extract and custard apple seeds extract which have anti-dandruff and anti head lice activity. Garlic extract was obtained by adding phosphate buffer with freeze-dry method, while custard apple seeds extract was obtained from maceration using petroleum ether. Garlic extract provides an anti-dandruff effect with a minimum inhibitory concentration (MIC) of $6.25 \mathrm{mg} / \mathrm{mL}$ and the smallest custard apple seeds extract (LD $100 \%, 3$ hours) which is $3.13 \mathrm{mg} / \mathrm{mL}$ can provide anti head lice effect. Variations in the concentration of the combination of garlic extract and custard apple seeds extract used in creambath preparations were (6.25 $\mathrm{mg} / \mathrm{mL}$ and $3.13 \mathrm{mg} / \mathrm{mL}),(12.5 \mathrm{mg} / \mathrm{mL}$ and $6.25 \mathrm{mg} / \mathrm{mL})$ and $(25 \mathrm{mg} / \mathrm{mL}$ and $12.5 \mathrm{mg} / \mathrm{mL})$. The resulting creambath preparations have characteristics that are light green, green tea flavored, homogeneous, semisolid form, o/w cream type, $\mathrm{pH}$ 5.85-6.25, viscosity 34,000-72,000 cps with thixotropic pseudoplastic flow properties, average size particle 34.31-57.66 $\mu \mathrm{m}$, anti-dandruff activity with diameters of inhibitory 9 , 12, and $16 \mathrm{~mm}$ in 72 hours incubation time and LD 100\% hair lice activity in 157, 133 and 105 minutes.

Keywords: Creambath preparations, garlic extract, custard apple seeds extract, anti-dandruff and anti head lice
\end{abstract}

\section{INTRODUCTION}

Dandruff is an abnormality characterized by excessive scaling, itching of the scalp is accompanied by or without signs of inflammation (Tjahjadi, 1995).

Dandruff can be caused by many factors, one of which is a fungus from the genus Malassezia or Pittosporum which is known to play an active role in causing dandruff (Saint-Leger et al., 1988; Saltshaker., 2004). Traditionally, many plants have anti-fungal activity, one of them is garlic (Allium sativum L.). The results showed that garlic has various benefits including anti-bacterial, antidiabetic and antifungal (London et al., 2011). Garlic has antifungal properties due to the chemical compounds of allicin and ajoene (Negri et al., 2011).

Misdiagnosis of head lice are common, especially in the egg phase is difficult to distinguish from other particles found in the hair such as dandruff, hair spray droplets, and dirt particles.

Head lice (Pediculus humans capitis) is a skin or head hair infection which is caused by an infestation of Pediculus humans var. capitis

*Corresponding author : Mudita

Email : mudita190@gmail.com
(Djoundi et al., 2007). Various classes of insecticidal drugs are used to treat head lice, such as pyrethrin, permethrin, lindane, carbaryl, but the use of insecticides has adverse effects, such as toxicity and potential resistance (Burns et al., 2004).

One of the plants that is efficacious as an anti-head lice is custard apple seeds (Annona squamosa L.). Custard apple seeds have been proven effective in killing head lice. Oleic acid and triglyceride content from custard apple seed extract showed anti head lice activity in vitro. Researchers has shown that petroleum ether extract from leaves and seeds killed more than $90 \%$ of head lice in vitro by 52 and 26 minutes respectively (Gritsanapan et al., 1996). Therefore, this study was conducted to develop creambath preparations using a combination of garlic extract and custard apple seeds to overcome dandruff and head lice.

\section{METHODOLOGY}

Garlic Dry Extract

100 grams of fresh garlic is washed with water, then garlic is mixed with $250 \mathrm{ml} 10 \mathrm{mM} \mathrm{pH}$ 7.0 phosphate buffer and homogenized, then the mixture is squeezed. The clear layer obtained was 
Table I. The Formula for Creambath Preparation of Combination of Garlic Extract and Custard Apple Seeds Extract

\begin{tabular}{|c|c|c|c|c|c|}
\hline \multirow{2}{*}{ No. } & \multirow{2}{*}{ Ingredients } & \multicolumn{4}{|c|}{ Concentration (\%) } \\
\hline & & Base & F1 & F2 & F3 \\
\hline 1. & Garlic Extract & - & MIC & $2 \times \mathrm{MIC}$ & $4 \times \mathrm{MIC}$ \\
\hline 2. & Custard Apple Seed extract & - & LD100\% & $2 \times \operatorname{LD} 100 \%$ & $4 \times$ LD $100 \%$ \\
\hline 3. & Vaseline Album & 6,2 & 6,2 & 6,2 & 6,2 \\
\hline 4. & Paraffin Liq & 13,8 & 13,8 & 13,8 & 13,8 \\
\hline 5. & Isopropyl Myristate & 1,5 & 1,5 & 1,5 & 1,5 \\
\hline 6. & Stearic Acid & 7,5 & 7,5 & 7,5 & 7,5 \\
\hline 7. & Glyceryl Monostearate & 5 & 5 & 5 & 5 \\
\hline 8. & Nipagin & 0,1 & 0,1 & 0,1 & 0,1 \\
\hline 9. & Nipasol & 0,05 & 0,05 & 0,05 & 0,05 \\
\hline 10. & TEA & 0,2 & 0,2 & 0,2 & 0,2 \\
\hline 11. & Xanthan Gum & 0,2 & 0,2 & 0,2 & 0,2 \\
\hline 12. & Green Tea Perfume & 0.1 & 0.1 & 0.1 & 0.1 \\
\hline 13. & Brilliant Green & 0,025 & 0,025 & 0,025 & 0,025 \\
\hline 14. & Aqua Distillate & ad 100 & ad 100 & ad 100 & ad 100 \\
\hline
\end{tabular}

filtered by passing a $0.22 \mu \mathrm{m}$ filter and then stored at $-70^{\circ} \mathrm{C}$ and dried garlic water extract with freeze drying (Shams-Ghahfarokhi et al., 2006).

\section{Rough Extract of Custard apple Seeds}

Fresh custard apple seeds are washed and dried in $55^{\circ} \mathrm{C}$ oven heat for 24 hours. Dry seeds are milled with a blender. $\pm 1.0 \mathrm{~kg}$ dry powder macerated with petroleum ether $(10 \mathrm{~L})$ for 2 days at room temperature $\left(25^{\circ} \mathrm{C}\right)$ then filtered, the mixture of the filtrate is thickened with the evaporator continued to the water batch until constant weight / obtain crude extract of custard apple seeds (Tiangda et al., 2000; Gritsanapan 1996).

\section{Determination of Anti-Fungal Activities from Garlic Extract}

The minimum inhibitory concentration (MIC) value as a minimum concentration value can inhibit the growth of Pityrosporum ovale which is characterized by the formation of clear zones after 24-72 hours (Harmita et al., 2005; Sitompul et al., 2016).

\section{Determination of Anti head lice Activities}

Testing of anti-head lice, custard apple seed extracts used in vitro techniques for head lice samples taken from school-age girls (9-13 years) and given treatment. $0.05 \mathrm{ml}$ of custard apple seed extract is put into a petri dish and spread thinly over a $2 \mathrm{~cm}^{2}$ zone. Seven same-sized head lice collected from the hair of a school girl were placed on a petri dish containing variations in concentration $(10 \% ; 15 \% ; 20 \% ; 25 \%$ and $30 \%)$. If the lice are immobile, it is determined as dead lice, calculated every 30 minutes until all head lice die (McCage et al., 2002).

\section{Creambath Preparations Combination of Garlic Extract and Custard apple Seed Extract}

The oil phase consists of Vaseline albums, mineral oil, isopropyl myristate, stearic acid, glyceryl monostearate, and nipasol. The oil phase is heated above the water bath. The water phase consists of TEA, xanthan gum, nipagin, and aquadestilata and is heated over a water bath to a temperature of $70^{\circ} \mathrm{C}$. Dried garlic extract was included in aquadestilata at $35^{\circ} \mathrm{C}$ together with crude extract of custard apple seeds added to base cream that had been formed and added aquadestilata to $100 \%$ of the formula weight (Damaranie et al., 2014). The formula for creambath preparation combined with garlic extract and custard apple seed extract (Table I).

\section{Determination of Anti-Fungal Activity in Creambath Preparations Combination of Garlic Extract and Custard apple Seed Extract}

Antifungal testing of cream samples by the diffusion method. Inoculated by Pityrosporum ovale (equivalent to McFarland standard 0.5 which is equivalent to the number of fungi or yeast as much as $5 \times 10^{6} \mathrm{cfu} / \mathrm{ml}$ ) as much as $200 \mathrm{uL}$ and flattened on the surface of the PDA in Petri using a spreader. Furthermore, the cream samples were weighed $65 \pm 5$ milligrams each and added $20 \mathrm{ml}$ of sterile aquadest on the $6 \mathrm{~mm}$ disc paper waiting to dry on LAF, then placed on the surface of PDA media that had been inoculated with Pityrosporum 


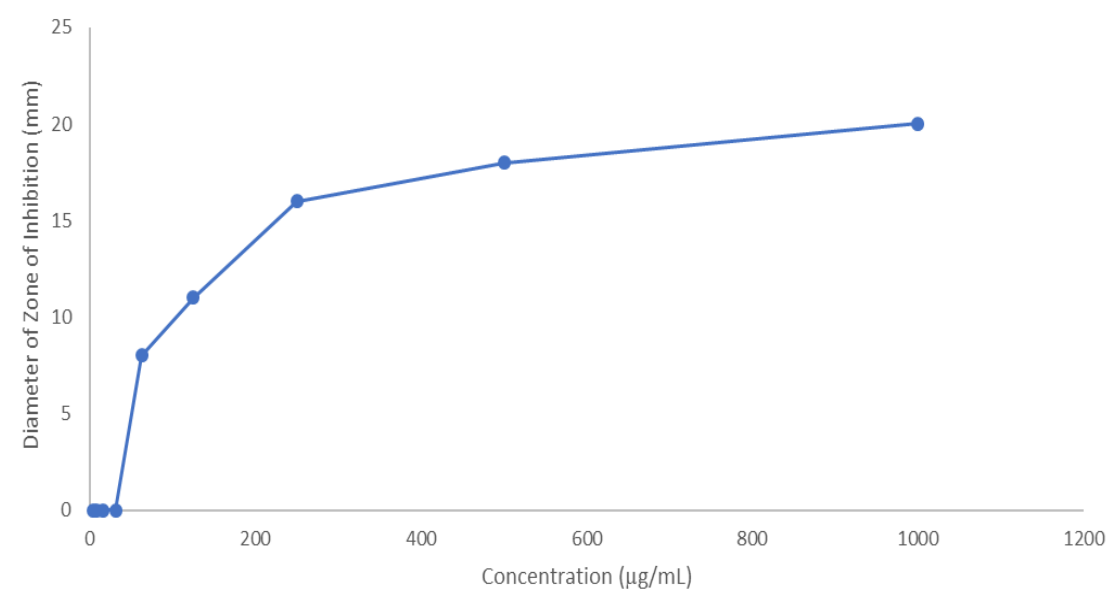

Figure 1. Graph of the results of testing the diameter of the ketoconazole inhibition zone

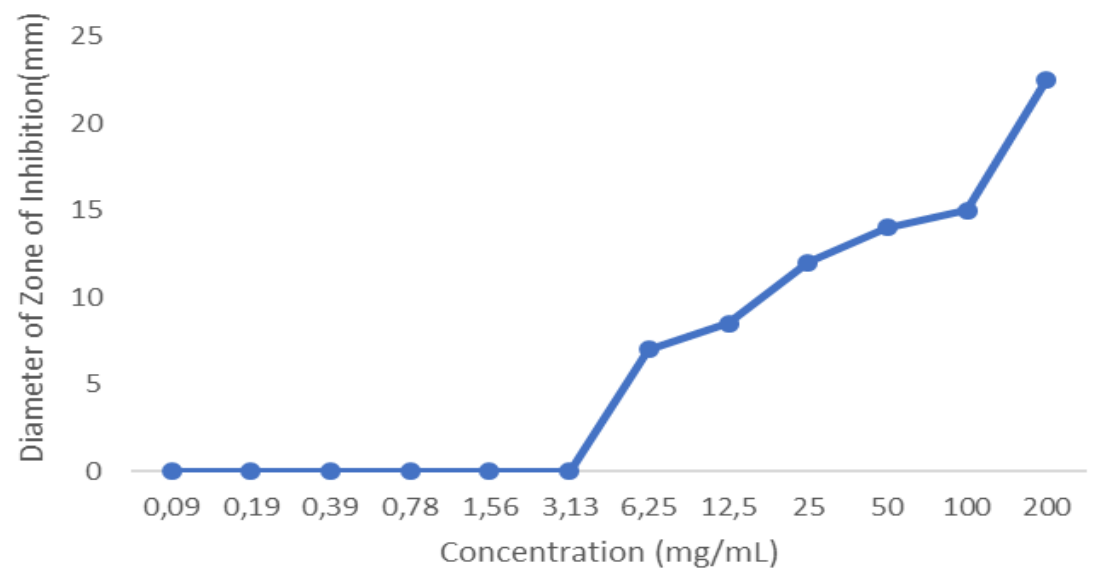

Figure 2. Graph of inhibition zone diameter of garlic extract

ovale, then incubated at $37^{\circ} \mathrm{C}$, for 24 hours. The clear zone that arises around the cylinder is measured in diameter. The minimum inhibitory concentration (MIC) value as a minimum concentration value can inhibit the growth of Pityrosporum ovale which is characterized by the formation of clear zones after 24 to 72 hours (Tiangda et al., 2000; Gritsanapan 1996).

Testing of anti-head lice activity of custard apple seed extracts used in vitro techniques for head lice samples taken from school-age girls (9-13 years) and given treatment. Approximately $50 \pm 5$ milligrams each of the creambath preparations were put into a petri dish and spread thinly over a $2 \mathrm{~cm}^{2}$ zone. Seven same-sized head lice collected from the hair of the school girl were placed on a petri dish containing creambath preparations. If the lice are immobilized then it is determined as dead head lice, counted the time until all head lice die (McCage et al., 2002).

\section{RESULTS AND DISCUSSION}

MIC Results and Measurement of Inhibited Zone Diameter

The concentration series of garlic extract was used from $0.0977-200 \mathrm{mg} / \mathrm{mL}$, and the series of positive standard concentrations (ketoconazole) from 3.9 -1000 $\mu \mathrm{g} / \mathrm{mL}$. The negative control used was methanol and sterile aquadest.

From the results of the observations it can be concluded that at concentrations of 3.91 to $31.25 \mu \mathrm{g} / \mathrm{mL}$ showed results (-) with no inhibition zone (clear) which means there is no inhibition of the growth of Pityrosporum ovale. So that the minimum inhibitory concentration (MIC) of ketoconazole against Pityrosporum ovale was 


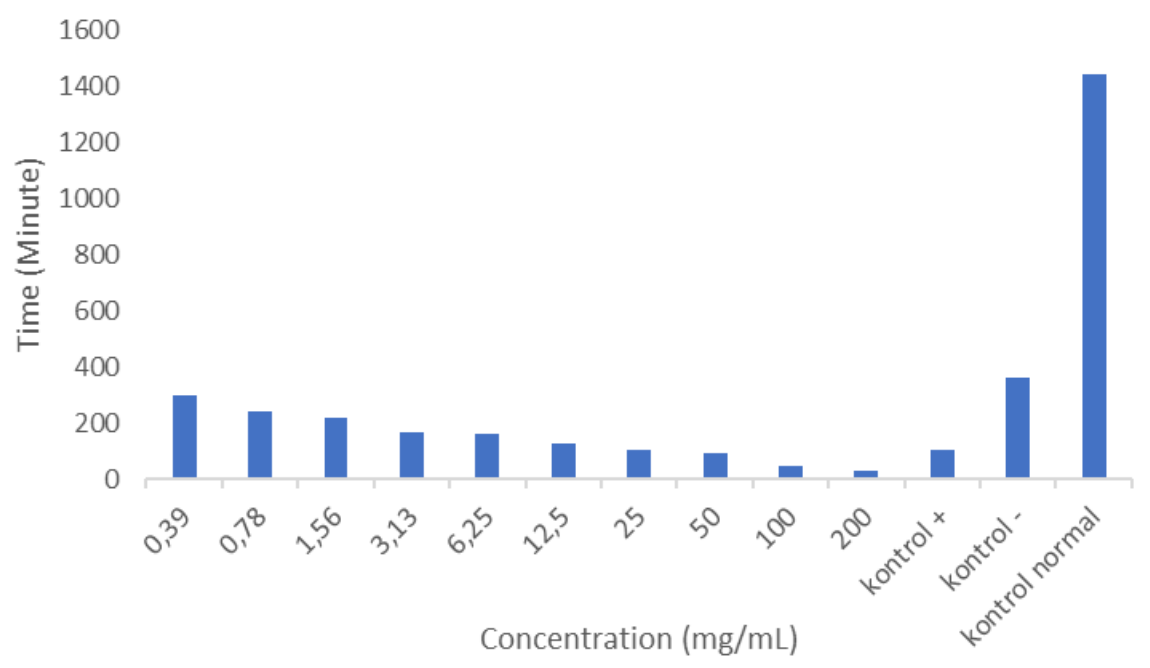

Figure 3. Diagram of the effect of concentrations of custard apple seed extract on time of death of head lice

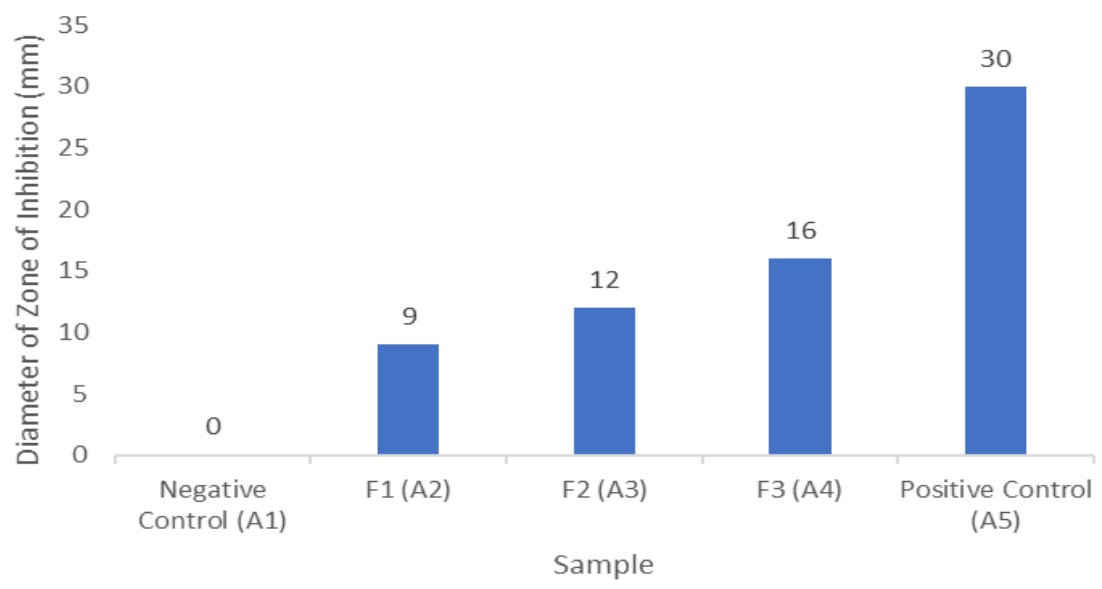

Figure 4. Diagram of inhibition of creambath combination of garlic extract and custard apple seed extract

determined to be $62.5 \mu \mathrm{g} / \mathrm{mL}$ with the inhibition zone formed at $8 \mathrm{~mm}$ with an incubation period of 3 days.

From the results of the observations it can be concluded that at concentrations of 0.09 to 3.13 $\mathrm{mg} / \mathrm{mL}$ showed the results (-) with no inhibition zone diameter formed meaning that there was no inhibition of the growth of Pityrosporum ovale So that the minimum inhibitory concentration (MIC) of garlic extract against Pityrosporum ovale is 6.25 $\mathrm{mg} / \mathrm{mL}$.

\section{Results for Anti-Hair Lice Activities for Custard apple Seed Extract}

The results of the examination of head lice death were based on $100 \%$ mortality of head lice within 180 minutes 21.59 in figure 3 . The concentration series of custard apple seed extract was used from $0.39-200 \mathrm{mg} / \mathrm{mL}$.

From the results of the observations it can be concluded that at concentrations of $0.39 \mathrm{mg} / \mathrm{mL}$ up to $1.56 \mathrm{mg} / \mathrm{mL}$ showed results that did not meet the requirements where all head lice showed mortality above the required time (above 180 minutes) (Tiangda et al., 2000; Intaranongpai et al., 2006) means that at 180 minutes there has not been a death of $100 \%$ of head lice.

At the concentration of Custard apple seed extract $3.13 \mathrm{mg} / \mathrm{mL}$ to $200 \mathrm{mg} / \mathrm{mL}$ showed mortality in all head lice with less than 180 minutes, and with an increase in the concentration of custard apple seed extract inversely proportional to the time needed to kill all lice. 


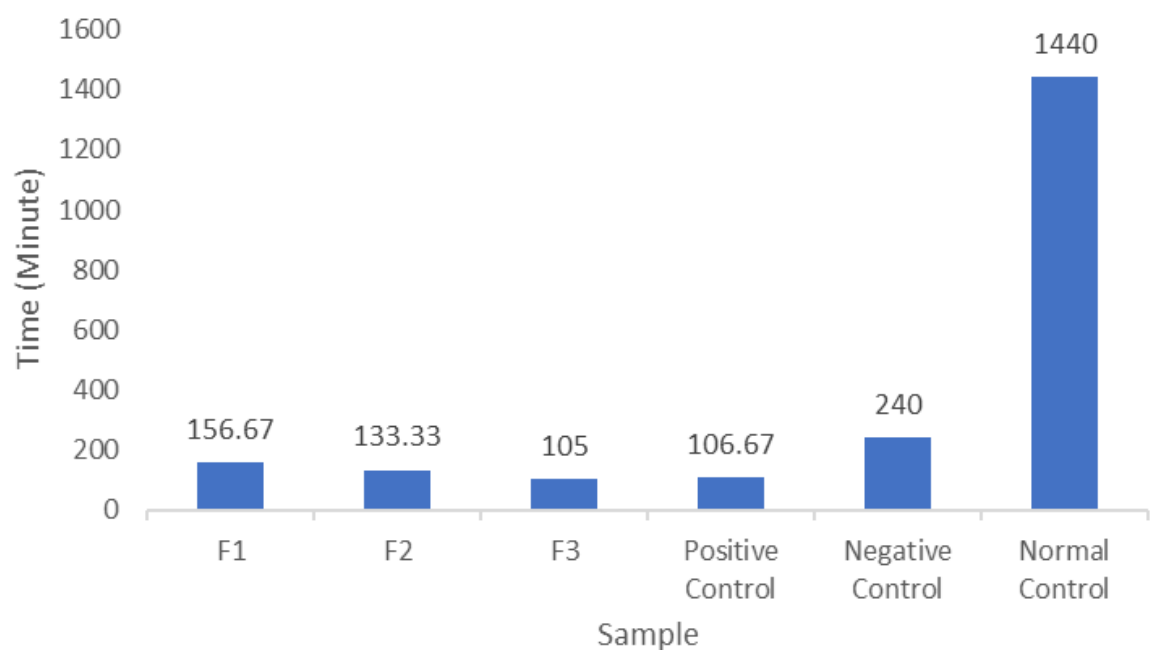

Figure 5. Diagram of The Effect of Creambath on The Combination of Garlic Extract

Table II. Characteristics of Creambath Preparations in Combination with Garlic Extract and Custard Apple Seed Extract

\begin{tabular}{|c|c|c|c|c|c|}
\hline No. & Characteristic & Base & F1 & F2 & F3 \\
\hline \multirow[t]{5}{*}{1.} & Organoleptic & & & & \\
\hline & Color & Light Green & Light Green & Light Green & Light Green \\
\hline & Odor & Green tea & Green tea & Green tea & Green tea \\
\hline & Homogeneity & Homogenous & Homogenous & Homogenous & Homogenous \\
\hline & Consistency & Semisolid & Semisolid & Semisolid & Semisolid \\
\hline 2. & $\mathrm{pH}$ & 6.25 & 6.03 & 5.94 & 5.85 \\
\hline 3. & Type of cream & $\mathrm{W} / \mathrm{O}$ & $\mathrm{W} / 0$ & $\mathrm{~W} / \mathrm{O}$ & $\mathrm{W} / \mathrm{O}$ \\
\hline 4. & Viscosity (10 rpm \& spindle no. 6) & $72,000 \mathrm{cp}$ & $49,500 \mathrm{cp}$ & $41,000 \mathrm{cp}$ & $34,000 \mathrm{cp}$ \\
\hline 5. & Flow Properties & Pseudoplastic & Pseudoplastic & Pseudoplastic & Pseudoplastic \\
\hline & & & Thixotropic & Thixotropic & Thixotropic \\
\hline 6. & Average Size Particle & $34,31 \mu \mathrm{m}$ & $39,16 \mu \mathrm{m}$ & $41,50 \mu \mathrm{m}$ & $57,66 \mu \mathrm{m}$ \\
\hline
\end{tabular}

Negative and normal controls showed negative results with no head lice deaths during the treatment time (180 minutes) so it can be concluded that negative controls did not influence the mortality rate of head lice.

The expected death of head lice is $100 \%$ within 180 minutes. The smallest concentration that can kill head lice within 180 minutes is 3.13 $\mathrm{mg} / \mathrm{mL}$, higher concentrations can kill $100 \%$ of hair lice at a faster time and smaller concentrations kill $100 \%$ of head lice in a longer time ( $>180$ minutes).

Characteristics of Creambath Preparations Combination of Garlic Extract and Custard apple Seed Extract

Creambath preparations are formulated using base creambath and 3 variations of combinations of garlic extract and custard apple seed extract. The characteristics of the formula for creambath preparation were a combination of garlic extract and custard apple (Table II).

Measurement Results of Inhibitory Zones of Creambath Preparations Combination of Garlic Extract and Custard apple Seed Extract

Creambath combination of garlic extract and custard apple seed extract which tested its activity against fungi Pityrosporum ovale was formula 1,2 , and 3 , negative control (base cream) and positive control (ketomed $\AA$ shampoo). The results of the examination of anti-dandruff activity and measurement result of the average inhibition zone produced (Figure 4).

From the results of the observations, it can be concluded that on the creambath base showed results (-) with no inhibition zone diameter formed which means that there is no inhibition of the growth of Pityrosporum ovale. So, it was 
determined that the base had no anti-dandruff activity in the absence of inhibition of the Pityrosporum ovale.

The biggest inhibition zone is produced by formula 3 which is $15.5 \mathrm{~mm}$ with an incubation time of 3 days. In formula 1 to formula 3, it forms an inhibitory region characterized by an increase in inhibition zone diameter at each increase in the concentration of the combination of garlic extract and custard apple seed extract. In the positive control, an inhibition zone of $30 \mathrm{~mm}$ was formed with an incubation time of 3 days.

\section{Results of Creambath Preparations Combination of Garlic Extract and Custard apple Seed Extract on Head Lice Death}

Creambath preparations used were negative control (base creambath), normal control (without treatment), creambath 1 - 3 formula and positive control (peditox $\AA$ shampoo).

From the observation in Figure 5, it can be concluded that negative controls and normal controls do not cause death in all head lice up to 180 minutes as required so that it can be determined that negative controls do not have acted as an anti head lice.

Formula 1 to formula 3 shows the death of all head lice with less than 180 minutes, and with an increased concentration of combinations of garlic extract and custard apple seeds, the time needed to kill all hair lice is getting shorter.

\section{CONCLUSION}

Garlic extract with minimum inhibitory concentration (MIC) of $6.25 \mathrm{mg} / \mathrm{mL}$ can provide anti-dandruff effects and custard apple seed extract with the smallest concentration $(100 \% \mathrm{LD}$, 3 hours) which is $3.13 \mathrm{mg} / \mathrm{mL}$ can provide anti head lice effect. The creambath combination concentration contains garlic extract and custard apple seed extract $(6.25 \mathrm{mg} / \mathrm{mL}$ and $3.13 \mathrm{mg} / \mathrm{mL})$, $(12.5 \mathrm{mg} / \mathrm{mL}$ and $6.25 \mathrm{mg} / \mathrm{mL})$ and $(25 \mathrm{mg} / \mathrm{mL}$ and $12.5 \mathrm{mg} / \mathrm{mL}$ ) and has met physio-chemical requirements, have anti-dandruff activity with 9, 12 and $16 \mathrm{~mm}$ inhibitory power (DDH) at 72 hours incubation time and 100\% LD head lice activity within 157, 133 and 105 minutes.

\section{REFERENCES}

Burns, D.A., Dalam: Burns, T., Breathnach, S.,, Cox, N., 2004(2), Rooks Textbook of Dermatology, pp. 446-8.

Damaranie, D., Widji, S., Mangestuti, A., 2014, Formulasi krim antioksidan ekstrak etanol daun ubi jalar ungu (Ipomoea batatas L.) sebagai anti-aging, Fakultas Farmasi, Universitas Airlangga.

Djuanda, Adhi, Mochtar, H., Siti. A,. 2007, Ilmu Penyakit Kulit dan Kelamin, p 119 - 120, Fakultas Kedokteran Universitas Indonesia, Jakarta.

Gritsanapan, W., Somanabandhu, A., Titirungruang, C., Lertchaiporn, M., 1996, A study on the antiparasitic activities and chemical constituents of extracts from the leaves and seeds of custard apple (Annonasquamosa Linn). Proceedings of Third NRCTJSPS Joint Seminar. 209, 15.

Harmita, Maksum, R., 2005, Analisis hayati, Edisi 2, h 1-5, 12-14, Ari Cipta Jakarta

Intaranongpai, J., Chavasiri, W., \& Gritsanapan, W., 2006, Anti-Head Lice Effect Of Annona Squamosa Seeds, Southeast Asian Journal of Tropical Medicine and Public Health, 37(3), $532-535$.

Londhe, V.P., Gavasane, A.T., Nipate, S.S., Bandawane, D.D., Chaudhari, P.D., 2011, Role of garlic (Allium sativum) in various disease : an overview, J Pharm Res Opinion.1(4):129, 34.

McCage, C.M., Ward, S.M., Paling, C.A., Fisher, D.A., Flynn, P.J., McLaughlin., 2002. Development of a paw paw herbal shampoo for the removal of head lice. Phytomedicine, 9(8):743, 8.

Negri, M., Salci, T.P., Shinobu-Mesquita, C.S., Capoci, I.R.C., Svidzinski, T.I.E., Kioshima, E.S,. 2014, Early state research on antifungal natural product. Molecules,19(3):2925, 56.

Saint-Leger, D., Kligman, A.M., Stoudemyer, T.J., 1988, The role of the resident micro flora in the pathogenesis of dandruff, J Soc Cosmet Chem, 40:109, 17.

Sawleshwarkar, S.N., Salgaonkar, V., Oberai, C., Multicenter, 2004, open-label, noncomparative study of a combination of polytar and zinc pyrithione shampoo in the management of dandruff, Indian J Dermatol Venereol Leprol, 70:25, 8.

Sitompul, M.B., YamLean, P.V., Kojong, N.S., 2016, Formulasi dan uji aktivitas sediaan sampo anti ketombe ekstrak etanol daun alamanda (allamanda cathartica l.) terhadap pertumbuhan jamur candida albicans secara in vitro, Jurnal Ilmiah Farmasi.

Shams-Ghahfarokhi, M., Shokoohamiri, M.R., Amirrajab, N., Moghadasi, B., Ghajari, A., Zeini, F et al., 2006, In vitro antifungal activities of Allium cepa, Allium sativum and ketoconazole against some 
pathogenic yeasts and dermatophytes. Fitoterapia, 77(4) 321, 3.

Tiangda, C.H., Gritsanapan, W., Sookvanichsilp, N., Limchalearn, A., 2000, Anti-headlice activity of a preparation of Annona squamosa seed extract, Southeast Asian J T rop Med Public Health, 31 (1) $174,7$.

Tjahjadi,S., 1995, Ketombe, Berkala ilmu penyakit kulit \& kelamin, 7(2) 33, 8. 